\title{
ANALISIS PATIENT SAFETY DITINJAU DARI PERILAKU CARING PERAWAT PADA PASIEN DENGAN RESIKO JATUH
}

\author{
Patient safety Analysis Review of Nurse Caring Behavior in Patients With Risk of \\ Fall
}

\author{
Rahmania Ambarika ${ }^{1}$, Novita Ana Anggraini² \\ ${ }^{1}$ IIK Strada Indonesia, Indonesia \\ ${ }^{2}$ IIK Strada Indonesia, Indonesia \\ Korespondensi: Rahmania Ambarika dan rahmania.ambar@gmail.com
}

\begin{abstract}
ABSTRAK
Latar Belakang: Pasien dengan resiko jatuh merupakan salah satu resiko insiden yang tidak diinginkan dalam lingkup rumah sakit. Resiko pasien jatuh hingga terjadi insiden mempunyai dampak merugikan bagi pasien, salah satu dampak yang merugikan adalah dampak cidera fisik yang mencakup luka lecet, luka robek, luka memar, bahkan dalam beberapa kasus berat jatuh dapat berakibat fraktur, perdarahan, dan cidera kepala. Tujuan Penelitian: Tujuan mengetahui hubungan perilaku caring perawat dengan Patient safety resiko jatuh. Metedologi: Metode penelitian yang digunakan dalam penelitian adalah Cross sectional. Populasi adalah Semua pasien pasien resiko jatuh. Besar sampel adalah 67 responden dengan menggunakan teknik Purposive sampling. Variabel Independen penelitian adalah Perilaku Caring. Variabel dependen adalah Patient safety resiko jatuh. Data dikumpulkan dengan menggunakan kuesioner, kemudian data dianalisis menggunakan uji Spearman Rho. Hasil: Hasil penelitian didapatkan bahwa peraku caring perawat cukup baik sebanyak 35 responden $(52,2 \%)$, Patient safety resiko jatuh yaitu cukup sebanyak 30 responden $(4,8 \%)$. Hasil penelitian didapatkan bahwa $\mathrm{p}=0,000$ terdapat hubungan perilaku caring perawat dengan Patient safety risiko jatuh. Kesimpulan: Perilaku caring perawat dengan Patient safety risiko jatuh memiliki hubungan yang signifikan, karena perilaku caring memberikan perawatan langsung, dan berespon terhadap setiap kondisi pasien.
\end{abstract}

Kata kunci: perilaku caring; perawat; Patient safety resiko jatuh.

\section{ABSTRACT}

Background: Patients with risk of falls is one of the risks of unwanted incidents within the hospital. The risk of the patient falling until an incident has an adverse effect on the patient, one of the adverse effects is the impact of physical injury which includes abrasions, torn wounds, bruises, even in some cases severe falls can result in fractures, bleeding, and head injuries. Objectives: To find out the relationship between Caring Behavior of Nurses and Patient safety Risk of Falling. Methodology: The research method used in the study is cross sectional. The population is all patient patients at risk of falling. The sample size is 67 respondents using purposive sampling technique. Independent variable of research is Caring Behavior. The dependent variable is the Patient safety risk of falling. Data was collected using a questionnaire, then the data were analyzed using the Spearman Rho test. Result: The results showed that the nurse caring nurse was quite good as many as 35 respondents (52.2\%), Patient safety risk fell 
that was enough as many as 30 respondents (4.8\%). The results showed that $p=0,000$ which means that there is a relationship between Caring Behavior of Nurses and Patient safety in Falling Risk. Conclusion: Nurse Caring Behavior With Patient safety The Risk of Falling has a significant relationship, because caring behavior give direct caring and responsif in each patient condition.

Keywords: Caring behavior; nurse; Patient safety risk of falling.

\section{PENDAHULUAN}

Pasien jatuh adalah salah satu insiden yang paling sering terjadi dalam lingkup rumah sakit. Insiden pasien jatuh mempunyai dampak merugikan bagi pasien, salah satu dampak yang merugikan adalah dampak cidera fisik yang mencakup luka lecet, luka robek, luka memar, bahkan dalam beberapa kasus berat jatuh dapat berakibat fraktur, perdarahan, dan cidera kepala (Miake-Lye et al, 2013). Peningkatan kejadian jatuh karena perilaku caring yang rendah terhadap pasien. Perilaku Caring merupakan sentral praktik keperawatan. Kebutuhan, tekanan dan batas waktu dalam lingkungan pelayanan kesehatan berada dalam ruang kecil praktik caring (Potter, 2009). Caring merupakan suatu cara pendekatan yang dinamis, dimana perawat bekerja untuk lebih meningkatkan kepeduliannya kepada klien terutama pasien resiko jatuh, dimana caring juga merupakan kunci dari kualitas pelayanan asuhan keperawatan (Potter, 2009).

Perilaku perawat dengan ditunjang kemampuan perawat yang baik sangat berperan penting dalam pelaksanaan keselamatan pasien. Perilaku yang tidak aman, lupa, kurangnya perhatian/motivasi, kecerobohan, tidak teliti dan kemampuan yang tidak memperdulikan dan menjaga keselamatan pasien berisiko untuk terjadinya kesalahan dan akan mengakibatkan cedera pada pasien, berupa Near Miss (Kejadian Nyaris Cedera/KNC) atau Adverse
Event

(Kejadian

Tidak

Diharapkan/KTD) selanjutnya pengurangan kesalahan dapat dicapai dengan memodifikasi perilaku. Perawat harus melibatkan kognitif, afektif dan tindakan yang mengutamakan keselamatan pasien. World Health Organization (WHO), 2014 Keselamatan pasien merupakan masalah keseahatan masyarakat global yang serius. Di Eropa mengalami pasien dengan resiko infeksi $83,5 \%$ dan bukti kesalahan medis menunjukkan 50$72,3 \%$. Angka-angka penelitian rumah sakit di berbagai Negara, ditemukan KTD dengan rentang 3,2-16,6\%. Data Patient safety tentang Kejadian Nyaris Cedera (KNC) dan Kejadian Tak Diharapkan (KTD) di Indonesia masih jarang, namun dipihak lain terjadi peningkatan tuduhan "mal praktek" yang belum tentu sesuai dengan pembuktian akhir. Insiden pelanggaran Patient safety 28,3\% dilakukan oleh perawat. Bawelle, 2013 secara keseluruhan program Patient safety sudah diterapkan, namun masalah dilapangan merujuk pada konsep Patient safety, karena walaupun sudah pernah mengikuti sosialisasi, tetapi masih ada pasien cedera, resiko jatuh, resiko salah pengobatan, pendelegasian yang tidak akurat saat oforan pasien yang mengakibatkan keselamatan pasien menjadi kurang maksimal.

Hasil penelitian yang dilakukan oleh Husein menyatakan bahwa 90\% pasien mengatakan tidak merasa nyaman berbicara dengan perawat, $84 \%$ dari jumlah tersebut memiliki 
pengalaman negatif karena perawat tidak memperhatikan kebutuhan pasien, terutama malam hari (Husein, 2006). Selain itu penelitian yang dilakukan oleh Khairina et al. di RSUD Kota Bandung menyatakan bahwa sebesar $52,64 \%$ perawat pelaksana belum melaksanakan caring saat melakukan pengelolaan pasca pemasangan infus. Hal ini didukung oleh penelitian yang dilakukan Nuryaningsih di rumah sakit Cengkareng, Jakarta Barat menyimpulkan bahwa responden menyatakan perawat yang belum caring $47,7 \%$, dengan keberadaan kurang baik $45,5 \%$, dalam memberikan kenyamanan kurang baik 38,6\%, dalam memberikan sentuhan kurang baik 47,7\%, dalam mendengarkan kurang baik 43,25\%, dalam mengenal pasien kurang baik $40,9 \%$, penerapan pencegahan pasien resiko jatuh yang kurang baik sebanyak 40,9\%5. Perilaku caring perawat tentu akan sangat berpengaruh terhadap kualitas pelayanan kepada klien.

Faktor

pendidikan

mempengaruhi perilaku kerja, makin tinggi pendidikan akan berbanding lurus dengan perilaku kerja seseorang (Pangewa, 2007). Perilaku kerja merupakan tanggapan atau reaksi seseorang yang timbul berupa perbuatan atau sikap maupun anggapan seseorang terhadap pekerjaannya (Maulana, 2013). Maka pendidikan akan berpengaruh terhadap perilaku kerja perawat yaitu dalam memberikan pelayanan keperawatan kepada pasien. Hal-hal yang dapat mempengaruhi perilaku caring perawat adalah usia, masa kerja, jenis kelamin dan tingkat pendidikan (Robbins, 2008). Perilaku Caring sejalan dengan tingkat pendidikan perawat merupakan pendidikan tinggi keperawatan yang dapat menimbulkan perubahan yang berarti terhadap cara perawat memandang asuhan keperawatan dan secara bertahap keperawatan beralih dari yang semula berorientasi pada tugas menjadi berorientasi pada tujuan yang berfokus pada asuhan keperawatan efektif dengan pendekatan holistik dan proses keperawatan. Hal ini sangat sesuai dengan tuntutan masyarakat pada saat ini yaitu mengharapkan pelayanan keperawatan yang berkualitas. Caring sebagai suatu proses yang berorientasi pada tujuan membantu orang lain tumbuh dan mengaktualisasikan diri (Dwidiyanti, 2007). Dampak yang pasien dapat saat perawat berperilaku caring yaitu pasien akan merasa aman dan nyaman, meningkatkan harga diri pasien, serta memperbaiki orientasi tentang kenyataan (Potter, 2009). Saat perawat mampu berlaku caring dengan memahami klien, pasien akan mendapatkan pelayanan pribadi tentang terapi yang diberikan perawat sehingga mengurangi resiko-resiko dan dampak negatif salah satunya resiko jatuh pasien.

Perilaku Caring perawat dalam pelayanan keperawataan sangatlah penting untuk meningkatkan kualitas pelayanan dan keselamatan pasien terutama pasien dengan resiko jatuh. Resiko jatuh pada pasien dapat dicegah dengan perilaku caring perawat yang baik. Patient safety resiko jatuh jika dikelola dengan baik maka resiko jatuh tidak akan terjadi. (Siagaan, 2010).

\section{TUJUAN PENELITIAN}

Tujuan mengetahui hubungan perilaku caring perawat dengan Patient safety resiko jatuh.

\section{METODE PENELITIAN}

Desain penelitian analitik korelasional dengan pendekatan cross sectional. Populasi Populasi pada penelitian ini adalah semua pasien resiko jatuh di IGD Puskesmas Wajak Kabupaten Malang bulan Januari- 
Februari 2021. Jumlah rata-rata responden per bulan adalah 90 responden. Tehnik sampel dengan Purposive Sampling didapatkan sebagian pasien resiko jatuh yang memenuhi kriteria inklusi berjumlah 67 responden. Variabel independen Perilaku Caring. Variabel dependen Patient safety. Instrumen yang digunakan dalam penelitian ini adalah Caring Behaviors Inventory I Sedangkan Patient Savety Resiko Jatuh berupa lembar kuesioner. Analisa data menggunakan Uji statistik dengan Spearman's rho.

\section{HASIL PENELITIAN \\ Karakteristik Responden}

Hasil penelitian didapatkan karakteristik responden dan ditampilkan pada tabel distribusi frekuensi di bawah ini.

Tabel 1. Distribusi Frekuensi Karakteristik Responden berdasarkan Umur

\begin{tabular}{llll}
\hline No & Umur & \multicolumn{1}{c}{$\sum$} & \multicolumn{1}{c}{$\%$} \\
\hline 1 & $17-25$ thn & 12 & 17,9 \\
2 & $26-35$ thn & 14 & 20,9 \\
3 & $36-45$ thn & 35 & 52,2 \\
4 & $46-55$ thn & 6 & 9,0 \\
\hline \multicolumn{2}{l}{} & $\mathbf{6 7}$ & $\mathbf{1 0 0}$ \\
\hline
\end{tabular}

Hasil penelitian didapatkan bahwa sebagian besar responden berumur 3645 tahun sebanyak 35 responden $(52,2 \%)$.

Tabel 2. Distribusi Frekuensi Karakteristik Responden berdasarkan Jenis Kelamin

\begin{tabular}{clcc}
\hline No & \multicolumn{1}{c}{ JK } & $\sum$ & $\%$ \\
\hline 1 & Laki-laki & 44 & 65,7 \\
2 & Perempuan & 23 & 34,3 \\
\hline & Total & $\mathbf{6 7}$ & $\mathbf{1 0 0}$ \\
\hline
\end{tabular}

Hasil penelitian didapatkan bahwa sebagian besar responden berjenis kelamin laki-laki sebanyak 44 responden $(65,7 \%)$.
Tabel 3. Distribusi Frekuensi Karakteristik Responden berdasarkan pendidikan

\begin{tabular}{clcc}
\hline No & Pendidikan & $\sum$ & $\%$ \\
\hline 1 & SD & 8 & 11,9 \\
2 & SMP & 21 & 31,3 \\
3 & SMA & 38 & 56,7 \\
\hline & Total & $\mathbf{6 7}$ & $\mathbf{1 0 0}$ \\
\hline & Hasil & penelitian & didapatkan
\end{tabular}

bahwa sebagian besar responden memiliki pendidikan SMA yaitu sebanyak 38 responden $(56,7 \%)$.

Tabel 4. Distribusi Frekuensi Karakteristik Responden berdasarkan Pekerjanaan

\begin{tabular}{|c|c|c|c|}
\hline No & Pekerjaan & $\sum$ & $\%$ \\
\hline 1 & Karyawan & 27 & 40,3 \\
\hline 2 & Swasta & 25 & 37,3 \\
\hline 3 & Tidak bekerja & 15 & 22,4 \\
\hline & Total & 67 & 100 \\
\hline
\end{tabular}

bahwa sebagian besar responden memiliki Pekerjaan karyawan sebanyak 27 responden $(40,3 \%)$.

\section{Karakteristik Variabel Penelitian}

Hasil penelitian didapatkan distribusi data variabel penelitian yaitu:

Tabel 5. Distribusi Frekuensi Responden berdasarkan Perilaku Caring

\begin{tabular}{cccc}
\hline No & Perilaku & $\sum$ & $\%$ \\
\hline 1 & Kurang & 5 & 7,5 \\
2 & Cukup & 35 & 52,2 \\
3 & Baik & 27 & 40,3 \\
\hline & Total & $\mathbf{6 7}$ & $\mathbf{1 0 0}$ \\
\hline & Hasil & penelitian & didapatkan
\end{tabular}

bahwa lebih dari setengah responden memiliki perilaku caring perawat cukup baik sebanyak 35 responden (52,2\%). 
Tabel 6. Distribusi Frekuensi Responden berdasarkan Patient safety Resiko Jatuh

\begin{tabular}{clcc}
\hline No & Patient safety & $\sum$ & $\%$ \\
\hline 1 & Kurang & 12 & 17,9 \\
2 & Cukup & 30 & 44,8 \\
3 & Baik & 25 & 37,3 \\
\hline & Total & $\mathbf{6 7}$ & $\mathbf{1 0 0}$ \\
\hline
\end{tabular}

Hasil penelitian didapatkan bahwa hampir setengah responden memiliki Patient safety resiko jatuh yaitu cukup sebanyak 30 responden $(44,8 \%)$.

\section{Analisa Uji Statistik}

Hasil uji statistik Spearman's rho dapat dilihat pada tabel dibawah :

Tabel 7. Hasil Uji Spearman's Rho

\begin{tabular}{ccc}
\hline Variabel & Sig. (2-tailed) & $\begin{array}{c}\text { Correlation } \\
\text { Coefficient }\end{array}$ \\
\hline $\begin{array}{c}\text { Perilaku } \\
\text { Caring }\end{array}$ & & \\
dengan & 0.000 & 0.864 \\
$\begin{array}{c}\text { Patient } \\
\text { safety }\end{array}$ & & \\
\hline
\end{tabular}

Hasil penelitian didapatkan bahwa $p=0,000$ dengan $p$ value $<0,05$, sehingga $\mathrm{H} 1$ diterima dan $\mathrm{H} 0$ ditolak yang berarti bahwa terdapat hubungan Perilaku Caring Perawat Dengan Patient safety Resiko Jatuh.

\section{PEMBAHASAN}

\section{Perilaku Caring Perawat}

Berdasarkan Hasil penelitian didapatkan bahwa peraku caring perawat cukup baik sebanyak 35 responden $(52,2 \%)$, dan paling sedikit memiliki perila caring yang kurang sebanyak 5 responden (7,5\%). Hasil penelitian didapatkan bahwa sebagian besar dari responden berumur 36-45 tahun sebanyak 35 responden $(52,2 \%)$, dan yang paling sedikit adalah berumur 46,55 tahun sebanyak 6 responden (9\%). Hasil penelitian didapatkan bahwa sebagian besar dari responden berjenis kelamin laki-laki sebanyak 44 responden $(65,7 \%)$, dan yang paling sedikit adalah berjenis kelamin perempuan sebanyak 16 responden $(34,3 \%)$.

Leininger (1979 dalam George, 2010) mengatakan bahwa caring adalah kepedulian langsung untuk memberikan bantuan, dukungan atau perilaku kepada individu atau kelompok melalui antisipasi kebiasaan untuk meningkatkan kondisi manusia atau kehidupan. Menurut Watson dalam George (2010) fokus utama dari keperawatan dari faktor-faktor cara yang bersumber dari perspektif humanistik yang dikombinasikan dengan dasar pengetahuan ilmiah. Watson mengembangkan sepuluh faktor carative tersebut untuk membantu kebutuhan pasien bertujuan terwujudnya integritas fungsional secara utuh dengan terpenuhinya kebutuhan biofisik, psikososial dan kebutuhan interpersonal. Watson dapat memberikan pemahaman pada pemberian proses asuhan keperawatan kepada pasien, pemberian bantuan bagi pasien dalam mencapai atau mempertahankan kesehatan atau mencapai kematian yang damai. Perawat memberikan keamanan dan perhatian serta empati pada pasien. Asuhan keperawatan tergambar pada seluruh faktor-faktor yang digunakan oleh perawat dalam pemberian pelayanan keperawatan pada pasien dan keluarga (Watson 1979, dalam Potter \& Perry, 2005). Faktor yang mempengaruhi perilaku caring diantranya kesiapan membantu, kemudahan, kenyamanan, antisipasi, hubungan saling percaya, dan pengawasan (Watson, 2009).

Berdasarkan hasil penelitian didapatkan bahwa paling banyak responden memiliki perilaku caring 
perawat yang baik. Berdasarkan penelitian Murtianingarum (2015) Hasil semakin bertambahnya usia maka semakin baik mempersepsikan perilaku caring perawat, hal sesuai dengan hasil penelitian karena karakteristik responden pasien yang paling banyak memiliki pendidikan SMA, dan berusia 36-45 tahun. Pendidikan yang tinggi dan usia yang matang maka diharapkan mampu berinteraksi dengan baik dan memiliki persepsi yang lebih luas terhadap perilaku caring yang diberikan perawat kepada pasien. Perilaku caring yang baik dapat bemanifestasi dengan mengenali nama klien, memanggil nama klien sesuai dengan yang disenangi pasien dan mengenali kelebihan dan karakteristik lain dari klien, selalu mendahulukan kepentingan klien dari pada kepentingan pribadi, memberikanwaktu kepada pasien walaupun sedang sibuk, memfasilitasi dan mendengarkan apa yang menjadi keluhan dan kebutuhan pasien, menghargai dan menghormati pendapat dan keputusan pasien terkait dengan perawatannya serta memberikan dukungan sosial untuk memenuhi kebutuhan dan meningkatkan status kesehatannya serta menggunakan sentuhan yang bermakna kesembuhan (Stuart \& Laraia, 2005). Didukung oleh hasil penelitian Murtianingarum (2015) yang mengatakan terdapat hubungan antara tingkat pendidikan perawat dengan perilaku caring perawat dalam melaksanakan asuhan keperawatan. Pasien dengan pendidikan yang baik, pengalaman yang baik diharapkan memiliki Sistem nilai yang menjembatani pengalaman perawatan dirumah sakit sehingga memiliki persepsi yang baik juga. Perawatan yang baik dapat dikembangkan melalui penilaian terhadap pandangan diri seseorang pasien, kepercayaan, interaksi dengan berbagai kebudayaan dari pengalaman pribadi pasien. Perilaku caring dapat ditingkatkan melalui pendidikan dan pelatihan secara bertahap kepada perawat sehingga pasien yang mendapatkan asuhan keperawatan menjadi semakin baik.

\section{Patient safety Resiko Jatuh}

Berdasarkan Hasil penelitian didapatkan bahwa paling banyak Patient safety resiko jatuh yait cukup sebanyak 30 responden $(44,8 \%)$, dan paling sedikit memiliki penilaian Patient safety resiko jatuh yang kurang sebanyak 12 responden (17,9\%). Hasil penelitian didapatkan bahwa paling banyak dari responden memiliki pendidikan SMA yaitu sebanyak 38 responden $(56,7 \%)$, dan yang paling sedikit adalah memiliki pendidikan SD sebanyak 4 responden (11,9\%). Hasil penelitian didapatkan bahwa paling banyak responden memiliki Pekerjaan karyawan sebanyak 27responden $(40,3 \%)$, dan yang paling sedikit adalah memiliki pekerjaan karyawan sebanyak 15 responden $(22,4 \%)$.

Patient safety adalah suatu sistem dimana rumah sakit membuat asuhan pasien lebih aman. Hal ini termasuk : assesment resiko, identifikasi dan pengelolaan hal yang berhubungan dengan risiko pasien, pelaporan dan analisis insiden, kemampuan belajar dari insiden dan tindak lanjutnya serta implementasi solusi untuk meminimalkan timbulnya resiko. (DepKes, 2016). Tujuan penanganan Patient safety Menurut Joint Commission International dalam Standar Akreditasi Rumah Sakit (2011), untuk mengidentifikasi pasien dengan benar, meningkatkan komunikasi secara efektif, meningkatkan keamanan dari high-alert medications, memastikan benar tempat, benar prosedur, dan benar pembedahan pasien, mengurangi resiko infeksi dari pekerja kesehatan, 
mengurangi resiko terjadinya kesalahan yang lebih buruk pada pasien. Faktorfaktor Patient safety resiko jatuh diantaranya, tidak dilakukan identifikasi faktor resiko, tidak dilakukan penilaian keseimbangan dan gaya berjalan pasien, kondisi situasional (Darmojo, 2004).

Berdasarkan hasil penelitian didapatkan bahwa hampir setengah responden memiliki tingkatan Patient safety resiko jatuh yaitu berada pada tingkatan yang cukup, pada indikator pengkajian awal tentang risiko anda jatuh, kriteria risiko anda jatuh, reassessment risiko anda pada saat terjadi perubahan terapi, tindakan pencegahan anda jatuh sesuai scoring yang sudah ditentukan dengan mengidentifikasi faktor resiko, tindakan pencegahan anda jatuh sesuai scoring yang sudah ditentukan dengan melakukan penilaian keseimbangan dan gaya berjalan, Melakukan tindakan pencegahan anda jatuh sesuai scoring yang sudah ditentukan dengan denan mengatur atau mengatasi faktor situasional (Sukesi, 2013). Pengaplikasian Patient safety dengan mengidentifikasi pasien dengan benar, meningkatkan komunikasi secara efektif, meningkatkan keamanan dari high-alert medications, memastikan benar tempat, benar prosedur, dan benar pembedahan pasien, mengurangi resiko infeksi dari pekerja kesehatan, mengurangi resiko terjadinya kesalahan yang lebih buruk pada pasien.

Patient safety resiko jatuh dapat dilakukan identifikasi dengan menggunakan dua identitas pasien (nama pasien sesuai tanda pengenal dan tanggal lahir pasien), Setiap pasien yang diobservasi memakai gelang identitas, Pasien diidentifikasi pada saat pemberian obat, Pasien diidentifikasi pada saat pengambilan darah dan spesimen lain untuk pemeriksaan, Pasien diidentifikasi saat pemberian darah, Pasien diidentifikasi saat melakukan prosedur tindakan. Perlu didentifikasi setiap indikator yang terlibat dalam penilaiiannya seperti Pengkajian awal yang perlu dilakukan, scoring resiko jatuh, Reassessment resiko jatuh, tindakan pencegahan sepeti memberikan tanda label resiko jatuh pada tempat tidur atau gelang pasien, Identifikasi faktor resiko seperti kekuatan otot, rentang gerak sendi, kelemahan otot, disabilitas, penilaian keseimbangan, gaya berjalan.

\section{Hubungan Perilaku Caring Perawat dengan Patient safety Resiko Jatuh}

Hasil penelitian didapatkan bahwa paling banyak responden memiliki memiliki penilaian perilaku caring yang cukup dengan patient safet resiko jatuh yang cukup sebanyak 26 responden $(38,8 \%)$. Hasil penelitian didapatkan bahwa $p<0,000$ dengan $a=0,05$ ( $p$ value $<\alpha$ ), yang berarti bahwa terdapat hubungan perilaku caring perawat dengan Patient safety risiko jatuh.

Pasien jatuh adalah salah satu insiden yang paling sering terjadi dalam lingkup rumah sakit. Insiden pasien jatuh mempunyai dampak merugikan bagi pasien, salah satu dampak yang merugikan adalah dampak cidera fisik yang mencakup luka lecet, luka robek, luka memar, bahkan dalam beberapa kasus berat jatuh dapat berakibat fraktur, perdarahan, dan cidera kepala (Miake-Lye et al, 2013). Peningkatan kejadian jatuh karena perilaku caring yang rendah terhadap pasien. Perilaku Caring merupakan sentral praktik keperawatan. Kebutuhan, tekanan dan batas waktu dalam lingkungan pelayanan kesehatan berada dalam ruang kecil praktik caring (Potter, 2009). Caring merupakan suatu cara pendekatan yang dinamis, dimana perawat bekerja untuk lebih 
meningkatkan kepeduliannya kepada klien terutama pasien resiko jatuh, dimana caring juga merupakan kunci dari kualitas pelayanan asuhan keperawatan (Potter, 2009).

Berdasarkan hasil penelitian terdapat hubungan yang signifikan antara Patient safety dengan perilaku caring. Perawat membantu berpartisipasi, membantu memperoleh pengetahuan dan meningkatkan kesehatan, sesuai yang diungkapkan Dwidiyanti (2007) yang menyatakan bahwa caring merupakan hubungan dan transaksi antara pemberi dan penerima asuhan untuk meningkatkan dan melindungi pasien sebagai manusia. Asuhan tersebut mempengaruhi kesanggupan pasien untuk sembuh Caring merupakan esensi dari keperawatan yang berarti juga pertanggungjawaban hubungan antara perawat-klien. Sesuai dengan Alligod (2006) yang menyatakan caring merupakan pengetahuan kemanusiaan, inti dari praktik keperawatan yang bersifat etik dan filosofikal. Sesuai dengan yang diungkapkan Nurachmah (2001) bahwa Caring sebagai tindakan yang bertujuan memberikan asuhan fisik dan perhatian emosi sambil meningkatkan rasa aman dan keselamatan klien. caring adalah asuhan yang diberikan secara terus menerus difokuskan pada perawatan fisik maupun mental dan meningkatkan rasa aman pasien. Perawat berkompeten dalam memberikan asuhan keperawatan kepada pasien dengan memberlakukan pasien sebagai manusia yang selalu ingin dihormati dan dihargai. Perilaku caring perawat dalam pelayanan keperawataan sangatlah penting untuk meningkatkan kualitas pelayanan dan keselamatan pasien terutama pasien dengan resiko jatuh.

Patient safety merupakan suatu sistem dimana rumah sakit membuat asuhan pasien lebih aman. Hal ini termasuk : assesment resiko, identifikasi dan pengelolaan hal yang berhubungan dengan risiko pasien, pelaporan dan analisis insiden, kemampuan belajar dari insiden dan tindak lanjutnya serta implementasi solusi untuk meminimalkan timbulnya resiko. (DepKes, 2016). Patient safety resiko jatuh jika dikelola dengan baik maka resiko jatuh tidak akan terjadi. Patient safety Resiko Jatuh akan juga menurunkan KTD di rumah sakit. Perawat yang berpendidikan lebih tinggi kinerjanya akan lebih baik karena telah memiliki pengetahuan dan wawasan yang lebih luas dibanding dengan perawat yang berpendidikan lebih rendah (Siagaan, 2010).

Resiko jatuh pada pasien dapat dicegah dengan perilaku caring perawat yang baik. Perilaku caring dan upaya pencegahan pasien jatuh sangatlah saling mendukung untuk meningkatkan kualitas pelayanan keperawatan. Paling banyak responden memiliki memiliki penilaian perilaku caring yang cukup dengan Patient safety resiko jatuh yang cukup $(38,8 \%)$. Hal ini menunjukkan bahwa semakin baik pelaksanaan perilaku caring maka Patient safety resiko jatuh maka semakin baik kecil, dengan begitu maka kualitas pelayanan asuhan keperawatan menjadi semakin baik. Pasien resiko jatuh perlu dilakukan pengkajian dan evaluasi secara terus menerus, pemberian tanda atau gelang pasien untuk mebedakan pasien dengan resiko jatuh dengan pasien yang lain, hal ini mempermudah dalam melakukan perawatan tindakan yang beresiko dan mengancam keselamatan pasien. . Perawat perlu juga dalam mengkaji kekuatan otot pasien, rentang sendi ataupun prognosa yang mempengaruhi kondisi pasien dan beresiko lainnya. 


\section{KESIMPULAN}

Adapun kesimpulan dalam penelitian ini adalah:

1. Hasil penelitian didapatkan bahwa lebih dari setengah responden memiliki perilaku caring perawat cukup baik sebanyak 35 responden $(52,2 \%)$.

2. Hasil penelitian didapatkan bahwa hampir setengah responden memiliki patient safety resiko jatuh yait cukup sebanyak 30 responden (44,8\%).

3. Hasil penelitian didapatkan bahwa $\mathrm{p}=0,000$ dengan $\mathrm{a}<0,05$, yang berarti bahwa terdapat hubungan perilaku caring perawat dengan patient safety resiko jatuh.

\section{DAFTAR PUSTAKA}

Arini, D. Yuliastuti, C. Lusia, R. (2019). Hubungan tingkat pengetahuan perawat tentang identifikasi dalam patient safety dengan pelaksanaannya di ruang rawat Inap RSUD SK. Lerik Kupang. Jurnal Ilmiah Keperawatan Stikes Hang Tuah Surabaya. Vol.14 No.2.

Asmadi., 2008. Konsep keperawatan dasar. Jakarta: EGC 12. Notoatmodjo, S., (2010). Promosi Kesehatan Teori \& Aplikasi, Edisi Revisi. Jakarta: Rineka Cipta.

Bawelle, S., Sinolungan, \& Hamel, R. (2013). Hubungan pengetahuan dan sikap perawat dengan pelaksanaan keselamatan pasien (pasien safety) di ruang rawat inap RSUD Liun Kandage Tahuna. E-Jurnal Keperawatan, Vol. 1 No 1, Februari 2017.

Dewi. (2014). Hubungan perilaku caring perawat dengan tingkat kecemasan anak usia sekolah akibat hospitalisasi di rumah sakit umum dr. H. Koesnadi kabupaten Bondowoso. Universitas Jember

Dwidiyanti, M., (2007). "Caring" Kunci Sukses Perawat/Ners Mengamalkan Ilmu. Semarang: Hasani

Husein, Muhammad., (2006). Patient Satisfication with Nursing Care Dera Ismail Khan Hospital, Gomal Madical College, Pakistan. Medical Journal: Vol. 32. No.1, Januari-Juni 2007: 2.

Khairina., Mardiah \& Adiningsih., (2012). Persepsi Perawat Mengenai Caring pada Pengelolaan Pasca Pemasangan Infus. Universitas Padjajaran, 2012.

Maulana. (2013). Analisa Perilaku Kerja Karyawan di De Bolivia Surabaya Town Square. Universitas Kristen Petra, 2013;(4).563-577

Mulyaningsih. (2013). Peningkatan Perilaku Caring Melalui Kemampuan Berpikir Kritis Perawat. Jurnal Management Keperawatan. Vol 1, No. 2, November 2013; 100- 106

Nursalam (2008) Konsep dan penerapan metodologi penelitian ilmu keperawatan. Jakarta: Salemba Medika.

Nuryaningsih. (2012). hubungan perilaku caring terhadap penerapan pencegahan pasie resiko jatuh di ruang rawat inap Rumah Sakit Umum Daerah Cengkareng Jakarta Barat. Universitas Esa Unggul; 2012.

Pangewa, M. (2007). Perilaku keorganisasian. Jakarta: Departemen Pendidikan Nasional

Potter, P. A. \& Perry, A. G., (2009). Fundamental keperawatan, buku 
Rahmania Ambarika \& Novita Ana Anggraini: Hubungan Pola Asuh Orang Tua terhadap Kemandirian Anak di TK Widya Bakti Desa Nongan, Kecamatan Rendang, Kabupaten Karangasem

1, edisi 7. Jakarta: Salemba Medika

Robbins, S.P. (2008). Perilaku Organisasi Organizational Behavior, Edisi 12. Jakarta: Salemba Empat.

Pangewa, M. (2007). Perilaku keorganisasian. Jakarta: Departemen Pendidikan Nasional

Siagaan, P.S. (2010). Manajemen Sumber Daya Manusia. Jakarta: Bumi Aksara.

Sugiyono. (2013). Metode Penelitian Kuantitatif, Kualitatif dan $R \& D$. Bandung: Alfabeta.
Sukesi. (2013). Upaya
peningkatan caring perawat terhadap kepuasan pasien diruang rawat inap RS Permata Medika Semarang, Junel Manajemen Keperawatan. 